\title{
Study of peanut husk ashes properties to promote its use as supplementary material in cement mortars
}

\section{Estudio de propiedades de las cenizas de cáscaras de maní para promover su uso como material suplementario en morteros cementicios}

\author{
J. KREIKER \\ jkreiker@ceve.org.ar \\ C. ANDRADA \\ carina_andrada@hotmail.com \\ M. POSITIERI b \\ mpositieri@gmail.com \\ M. GATANI a \\ marianagatani@ceve.org.ar \\ E. Q. CRESPO ${ }^{\circ}$ \\ equintana97@gmail.com
}

\begin{abstract}
The properties of peanut husk ashes as a potential supplementary material in cement mortars were studied in the laboratory. The ashes were prepared in an electric furnace at 500,650 and $800^{\circ} \mathrm{C}$ during 180 minutes and used without further treatment. The characterization of ashes includes X-Ray fluorescence, X-Ray diffraction, SEM, and determination of pozzolanic activity by conductivity. The ashes were tested in mortars as partial substitute of Portland cement, in a rate of $15 \%$ of substitution. The compression strength of mortars was evaluated between 7 and 120 days, for probes prepared using a proportion of cement:sand of $1: 3$ on weight with water/cement ratio of $0,5 \mathrm{v} / \mathrm{v}$. It was observed that the calcinations conditions influenced the behavior of the ashes, giving better results the ashes obtained at $500{ }^{\circ} \mathrm{C}$. The compression tests showed values near to $70 \%$ at 7 days but higher than $80 \%$ after 28 days for mortars prepared with ashes, respect to the cement mortar reference.
\end{abstract}

Keywords: peanut husk ashes, supplementary materials for cement mortar.

\section{Resumo}

Se estudiaron en el laboratorio las propiedades de las cenizas de cáscaras de maní como un potencial material suplementario para morteros de cemento. Las cenizas fueron preparadas en un horno eléctrico a 500,650 y $800^{\circ} \mathrm{C}$ durante 180 minutos y utilizadas sin ningún acondicionamiento posterior. La caracterización de las cenizas incluye Fluorescencia de Rayos-X, Difracción de Rayos-X, Microscopia Electrónica de Barrido (SEM) y determinación de la actividad puzolanica por conductimetria. Las cenizas fueron ensayadas en morteros reemplazando un $15 \%$ de este material por cemento Portland. Se prepararon probetas usando una proporción cemento:arena 1:3 en peso con una relación agua/cemento 0,5 v/v. Las probetas fueron ensayadas para determinar la resistencia a la compresión a edades entre 7 y 120 días. Se observó que las condiciones de calcinación de las cáscaras de maní influyen en el comportamiento de las cenizas, siendo $500^{\circ} \mathrm{C}$ la temperatura óptima de calcinación. Los ensayos de resistencia a la compresión arrojaron valores cercanos al 70 \% respecto del patrón a los 7 días y mayores al $80 \%$ luego de 28 días para morteros preparados con cenizas.

Palavras-chave: cenizas de cáscaras de maní, material suplementario para morteros de cemento.

\footnotetext{
Experimental Centre for Economic Housing (CEVE) - National Council for Scientific and Technological Research (CONICET) - Economical Housing Association (AVE), Córdoba, Argentina;

Center for Research, Development and Transfer of Materials and Quality (CINTEMAC), National Technological University, Córdoba Regional Faculty (UTN-FRC), Córdoba, Argentina;

National Technological University, Córdoba Regional Faculty (UTN-FRC), Córdoba, Argentina.
} 


\section{Introduction}

Peanut husks (Arachis Hypogaea) are an abundant agroindustrial waste in the region of Córdoba, Argentina, concentrating the 95\% of the country's peanut production. Almost 1 million tons were produced in 2011, generating around three hundred thousand tons of husks as waste (Cámara Argentina del Maní, 2012) [1]. Nowadays, peanut husks are used in the elaboration of panels [2], production of feed lots and for the manufacture of activated carbon [3]. The main use is as fuel in industrial processes, which generates an important amount of ashes used as landfill without added value, estimating a production of thirty tons per day of waste [4]. The cement industry is considered as highly contaminating, and several developments have been achieved in order to make the technologies of construction involving this binder material becomes more sustainable [5]. In this sense, the use of supplementary materials for cement has been widely recognized as a sustainable alternative. In general, ashes from industrial processes (fly ashes, silica fume, slag, etc.) have demonstrated very good properties as pozzolans, because they exhibit binder behavior. This sort of ashes have been studied for many years with interesting results regarding the physical and mechanical properties and the durability of mortars containing these materials as supplement $[6,7,8$, $9,10,11]$.

In addition, ashes from agro industrial wastes are also being used as supplementary binder materials, and many research works have been done upon these wastes, for instance rice husk ashes $[12,13,14,15,16]$, wheat straw ashes [17] , sugarcane bagasse ashes [18, 19, 20], palm oil ashes [21], dust wood ashes [22]. It has been demonstrated that cement added with these ashes have a similar or better behavior than normal concrete at ages beyond 28 days

It is well known that the pozzolanic properties of the ashes will depend on its chemical composition, parameter associated to the nature of agro industrial waste, and to its morphology and crystallographic properties, parameters associated to its burnt conditions[23].

Very few studies have been done upon peanut husk ashes. Isolated examples explore the use of this waste for heavy metal removal [24], or in degumming and refining soy oil [25]. Also, none significant literature was found about its potential use as a supplementary material for mortars, finding only a description as a pozzolans type $N$ [26] but with limited information about its characterization. The objective of this study was to characterize chemical and morphologically the peanut husk ashes prepared in laboratory controlled conditions and determine its pozzolanic behavior, in order to evaluate its potential use as a supplementary material for cement of mortars. This work includes the physical, chemical and morphological characterization of ashes prepared at 500,650 and $800^{\circ} \mathrm{C}$, the pozzolanic behavior for conductimetric method and the compression strength tests of mortars resulting of the replacement of a $15 \%$ of cement with ashes at different ages, for corroborate the results.

\section{Materials and experimental program}

\subsection{Materials used}

The peanut husks were provided by Maglione e Hijos S.R.L, from its production plant located on Las Junturas, Córdoba, Argentina. The husks were milled and only those retained on the $1 \mathrm{~mm}$ sieve were used. The Ashes were prepared calcinating husks in an electric furnace at 500,650 y $800^{\circ} \mathrm{C}(\mathrm{PH}-1, \mathrm{PH}-2, \mathrm{PH}-3$, respectively), with a heating rate of $10^{\circ} \mathrm{C} / \mathrm{min}$, and kept at the scheduled temperature for 3 hours. At the end of this process, the ashes were cooled by opening the oven until reaching the room temperature, and used without further conditioning. Ordinary Portland Cement (OPC) type CPF 40 provided by Holcim conforming IRAM 50000 norms was used. Grade river sand with fineness modulus of 4.98 determined according IRAM 1505 norms, and specific gravity of 2.65 determined according IRAM 1520 norms, was aggregated. $\mathrm{Ca}(\mathrm{OH})_{2}$ Anhedra (analytical grade) and $\mathrm{H}_{2} \mathrm{O}$ MilliQ quality were used for conductivity tests. Cement mortars were made using water from line supply, without purification.

\subsection{Testing procedures}

\subsubsection{Physical and chemical analysis of ashes}

The ashes particle size distribution was determined by gravimetric assay according to IRAM 1505 norms, using a $0.001 \mathrm{~g}$ precision balance. The ashes specific gravity was determined according IRAM 1520 norms. The ashes mineralogical analysis was carried out by $\mathrm{X}$-Ray diffraction (XRD) analyzing the samples prepared in random mounts in a Phillips X-Pert PRO PW3040/60 diffractometer, with $\mathrm{Cu} \mathrm{K \alpha} \mathrm{X}$-ray radiation, Si monochromator, at $40 \mathrm{Kv}$ and 30 $\mathrm{mA}$, step scan at $0.3^{\circ} / \mathrm{min}$ and step size of $0.02^{\circ} 2 \theta$. Peaks assignment was made by comparison using the data base of the software $X$ 'Pert Highscore. Microstructure morphology was observed with a scanning electron microscopy (SEM) using a FE-SEM Ligma apparatus. Chemical composition was determined by X-Ray fluorescence (XRF) using a Phillips PW 1400 equipment, and comparing the intensities of signals with standard references samples.

\subsubsection{Pozzolanic activity by conductimetric test}

The pozzolanic activity of ashes was evaluated according to the basic method which consist in evaluating the conductivity of a $\mathrm{Ca}(\mathrm{OH})_{2}$ solution in presence of the pozzolanic material and the evolution of this parameter on time [27]. We used the modification proposed by Payá et al. [28] for ashes with high content of ions, which evaluate the conductivity by a period of $600 \mathrm{~h}$. For this experience $200 \mathrm{~mL}$ of a $\mathrm{Ca}(\mathrm{OH})$, solution with a conductivity value of approximately $7 \mathrm{mS} / \mathrm{cm}$ was kept at $40 \pm 1^{\circ} \mathrm{C}$ with continuous stirring. Then, $5 \mathrm{~g}$ of pozzolanic material were added to the solution, and the conductivity was registered over time (sample A). On the other hand, the same experience was carried out evaluating the conductivity of the pozzolanic material in MilliQ water (blank $B)$. Finally the pozzolanic behavior of the material was estimated analyzing the graphic obtained by the difference between sample $A$ and blank $B(A-B)$.

\subsubsection{Compressive strength}

Compressive strength tests were carried out according to IRAM 1622 norms. Prismatic test specimens of $4 \times 4 \times 16 \mathrm{~cm}$ were made by replacing $15 \%$ of cement with previously described ashes: $\mathrm{PH}-$ 1, $\mathrm{PH}-2$, and $\mathrm{PH}-3$. A binder:sand proportion of $1: 3$ on weight and 


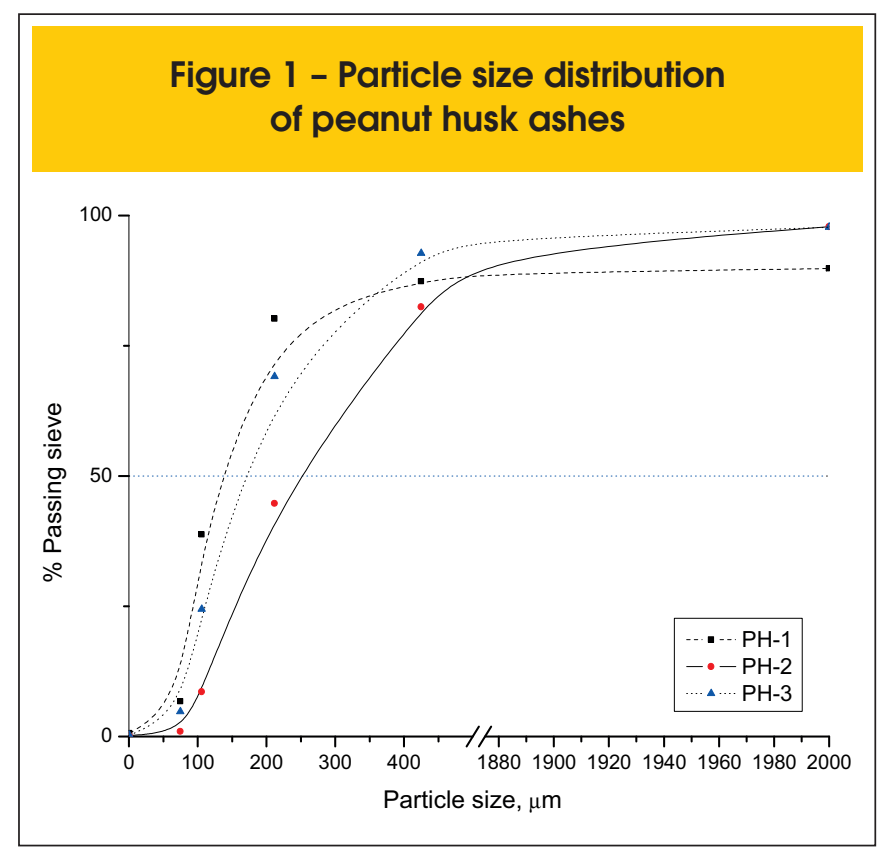

a water/cement $(\mathrm{W} / \mathrm{C})$ rate of 0.5 , was used. The specimens were compacted using a vibrating table, and then covered overnight with wet plastic sheets. After twenty four hours, the probes were removed from their molds. Finally the probes were cured in water at $20^{\circ} \mathrm{C}$ until the point of test ages of $7,14,28,60,90$ and 120 days. Compressive strength tests were carried out in a $30 \mathrm{t}$ essay press, where each specimen was compressed and the maximum sustained load was registered. Three specimens were tested at each testing age and the average value was reported. The data is accepted when measurements have a $\mathrm{CV}<5 \%$ (coefficient of variation), and we apply de Grubbs Contrast to discard suspected point with a confidence interval of $95 \%$.

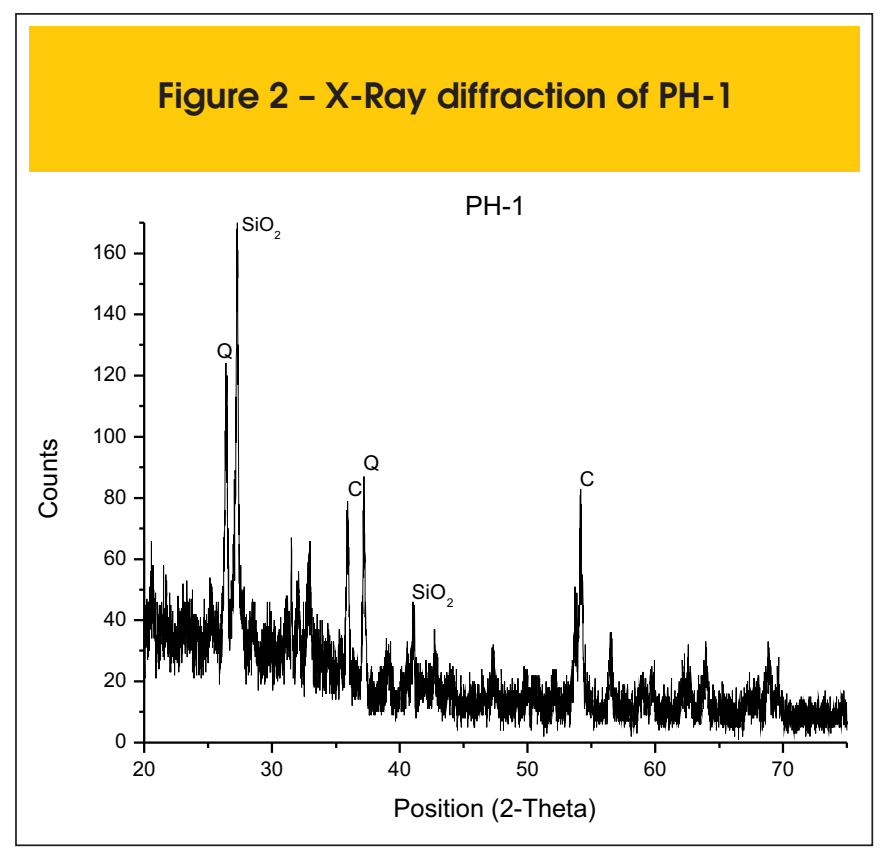

Figure 3 - X-Ray diffraction of PH-2

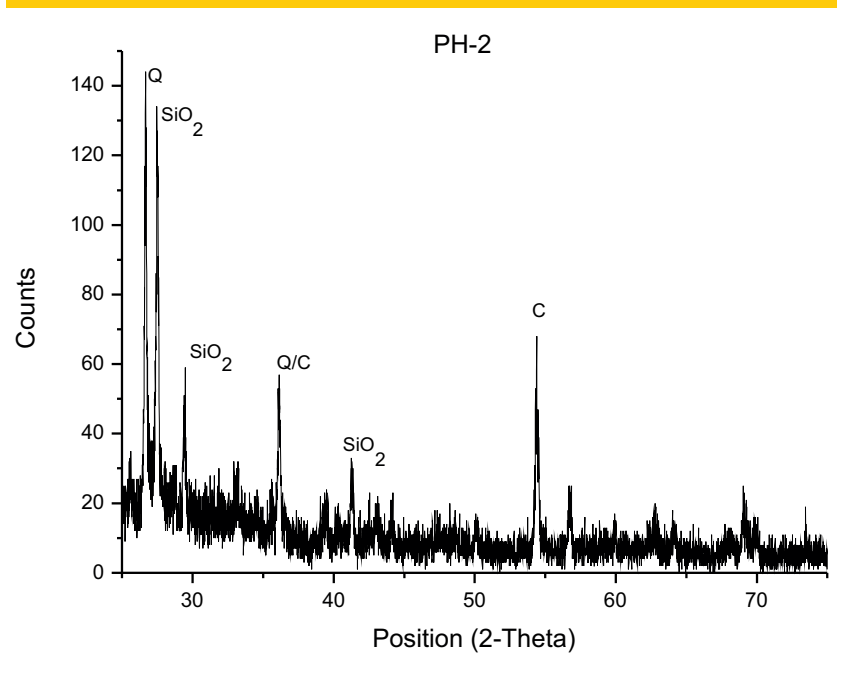

\section{Results and discussions}

\subsection{Physical and chemical analysis of ashes}

The ashes particle size distribution curves are shown in Fig. [1]. It is noted that the particles of ashes without grind, have a heterogeneous distribution and that the major percentage is around 100 and $200 \mathrm{~mm}$. The specific gravity test of ashes $\mathrm{PH}-1, \mathrm{PH}-2, \mathrm{PH}-3$ showed an average value of $0.39 \mathrm{~g} / \mathrm{cm}^{3}$.

The mineralogical analysis of ashes carried out by $\mathrm{X}$-ray diffraction is shown in Fig. [2], Fig. [3] and Fig. [4], for PH-1, PH-2 and PH-3 respectively. Small quantities of crystal-phases, as Quartz (Q), Cristobalite

Figure 4 - X-Ray diffraction of PH-3

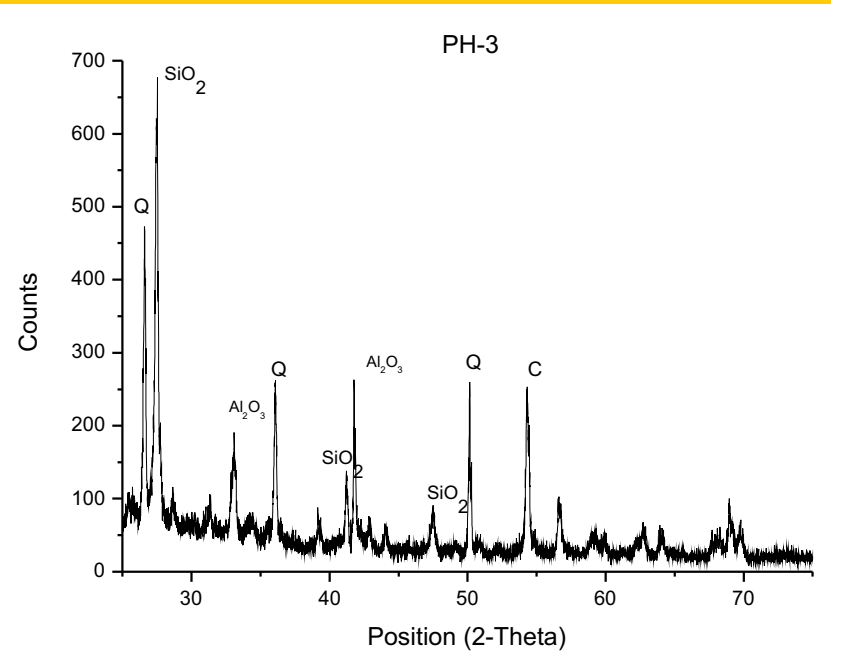




\section{Figure 5 - SEM of $\mathrm{PH}-1$ at $700 \mathrm{X}$ and $10 \mathrm{KX}$}

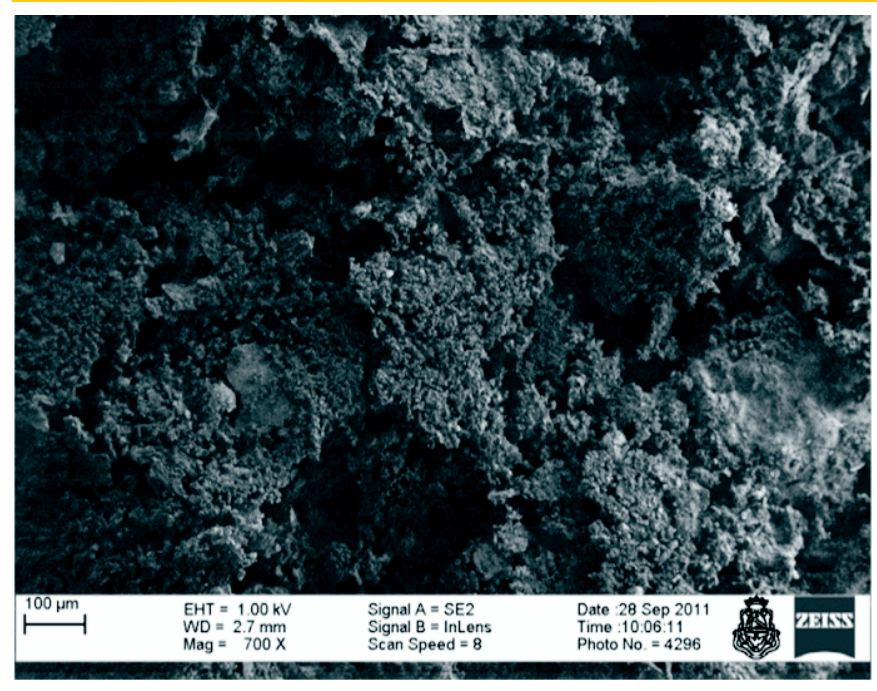

(C) and $\mathrm{SiO}_{2}$, are present in all cases, but their intensities are more significant at $800^{\circ} \mathrm{C}$, which is consistent with the reported by MartirenaHernandez et al (2000) [13]. Crystal phases of $\mathrm{Al}_{2} \mathrm{O}_{3}$ were observed in $\mathrm{PH}-3$ but not in $\mathrm{PH}-1$ and $\mathrm{PH}-3$. There are no significant crystallographic pattern differences between ashes obtained at $500^{\circ} \mathrm{C}$ and $650^{\circ} \mathrm{C}$. Fig. [5] shows the PH-1 SEM microscopy images with a $700 \mathrm{X}$ and $10 \mathrm{KX}$ magnifications. Due to the similar superficial characteristics of $\mathrm{PH}-2$ and $\mathrm{PH}-3$ with $\mathrm{PH}-1$, their images are not shown. It is seen that unmilled ashes exhibit a heterogeneous surface at $700 \mathrm{X}$. And

\begin{tabular}{|c|c|c|c|}
\hline \multicolumn{4}{|c|}{$\begin{array}{l}\text { Table } 1 \text { - Composition \% by mass, } \\
\text { of ashes } \mathrm{PH}-1, \mathrm{PH}-2 \text { and } \mathrm{PH}-3\end{array}$} \\
\hline Oxides & PH-1 & PH-2 & $\mathrm{PH}-3$ \\
\hline $\mathrm{S}_{1} \mathrm{O}_{2}$ & 34,1 & 35,8 & 36,6 \\
\hline $\mathrm{A}_{1} 2 \mathrm{O}_{3}$ & 11,6 & 10,8 & 10,3 \\
\hline $\mathrm{F}_{\mathrm{e}} 2 \mathrm{O}_{3}$ & 1,9 & 1,95 & 2,2 \\
\hline $\mathrm{CaO}$ & 13,1 & 13,7 & 18,1 \\
\hline $\mathrm{K}_{2} \mathrm{O}$ & 7,1 & 7,3 & 6,4 \\
\hline $\mathrm{MgO}$ & 7,3 & 5,7 & 7,2 \\
\hline $\mathrm{MnO}$ & 0,2 & 0,3 & 0,3 \\
\hline Sr ppm & 570 & 555 & 548 \\
\hline Pb ppm & 28 & 17 & 16 \\
\hline Zn ppm & 168 & 151 & 143 \\
\hline Cu ppm & 28 & 21 & 25 \\
\hline Ni ppm & 8 & 6 & 6 \\
\hline Cr ppm & 16 & 15 & 15 \\
\hline Ba ppm & 1050 & 1059 & 1015 \\
\hline
\end{tabular}

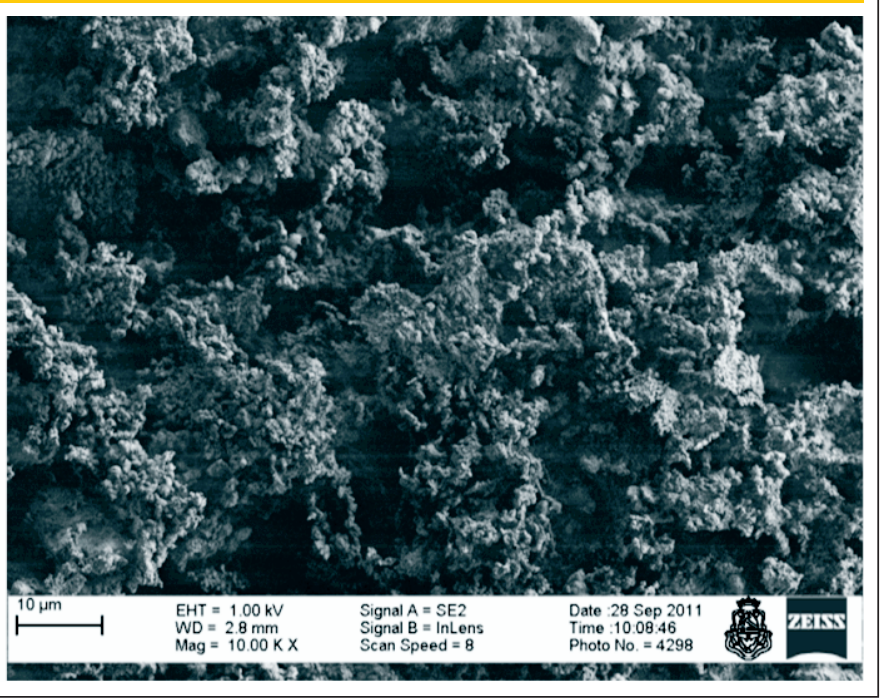

even presenting particles without a defined shape, they maintain some characteristic such as the husks structure. At $10 \mathrm{KX}$ a more homogeneous surface with micropores is observed.

Chemical composition of ashes determined by X-Ray fluorescence is presented in Table [1].

The sum of silica, aluminium, and iron oxides contents is in all cases almost a $50 \%$ of the total, corresponding to a type $\mathrm{C}$ pozzolan, according to ASTM-C618 norms. The content of alkali oxides $\mathrm{K}_{2} \mathrm{O}$ and $\mathrm{Na}_{2} \mathrm{O}$ is higher than $1.5 \%$ permitted by norm, making it not advisable for some applications, because of the undesirable alkaliaggregate reaction in cement mortars [29, 30]. On the other hand, the high content of $\mathrm{MgO}$ might give expansive reactions [31], an undesirable property of cement mortars. The main disadvantage of this type of ashes is the low content of $\mathrm{SiO}_{2}$ in comparison with other ashes from burnt agro-industrial wastes [32].

\subsection{Pozzolanic activity by conductimetric test}

The pozzolanic behavior of ashes was rudely determined by the reactivity in an unsaturated lime solution at $40^{\circ} \mathrm{C}$. The graphics of conductivity versus time for $\mathrm{PH}-1, \mathrm{PH}-2$ and $\mathrm{PH}-3$ in lime solution $(A)$, in $\mathrm{H}_{2} \mathrm{O}(\mathrm{B})$, and the difference between both graphics (A-B) are presented in Fig. [6], Fig. [7] and Fig. [8], respectively. An important increment on conductivity for ashes in pure water is observed, probably due to the presence of $\mathrm{CaO}, \mathrm{K}_{2} \mathrm{O}$, and other ions in smaller proportions, which are dissolved in water in these conditions. This effect was taken in account in the estimation of conductivity decrement for lime solution after the reaction with ashes. The difference between these graphics (A-B) showed clearly the reaction of consumption of $\mathrm{Ca}^{++}$, typical for pozzolanic materials. In the period of time evaluated, the conductivity decreased up to 1-2 mS/ $\mathrm{cm}$ in all cases, but it is worth noting a little difference on PH-1 conductivities, which might be attributed to a better pozzolanic behavior for this ashes prepared at $500{ }^{\circ} \mathrm{C}$, Fig. [9]. These observations agree with X-Ray diffraction graphics, which indicate the bigger 


\section{Figure 6 - Conductivity of ashes, graphics (A-B)}

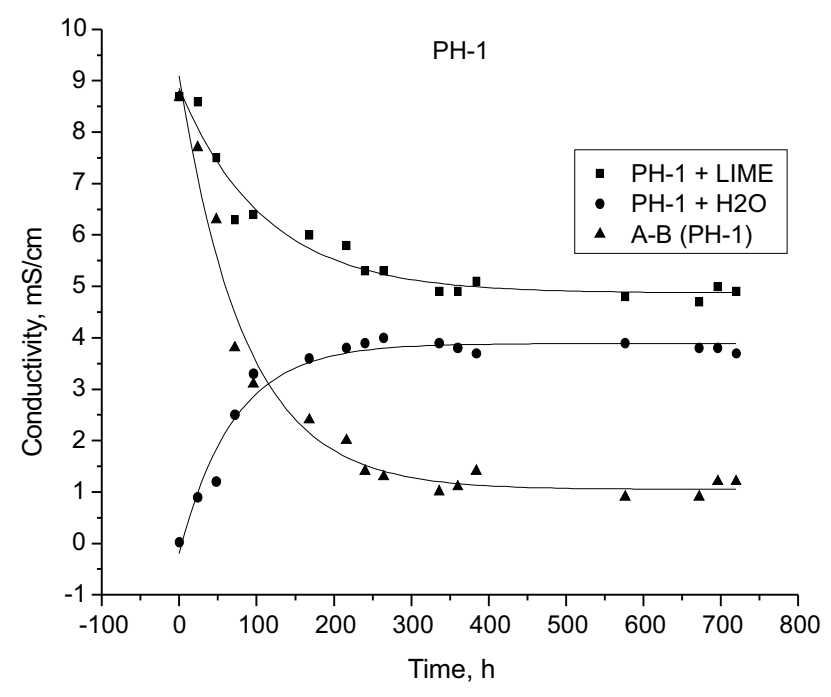

presence of amorphous silica at low temperatures meaning a better pozzolanic behavior, as was also reported by other authors[33].

\subsection{Compressive strength}

The Table 2 shows the results of compressive strength tests for mortars made with $\mathrm{PH}-1, \mathrm{PH}-2$ and $\mathrm{PH}-3$, together with the specimen without ashes, M0.

The behavior of compressive strength is similar for $\mathrm{MPH}-2$ and $\mathrm{MPH}-$ 3 between 7 and 120 days. The compressive strength of MPH-1 is

\section{Figure 7 - Conductivity of ashes, graphics (A-B)}

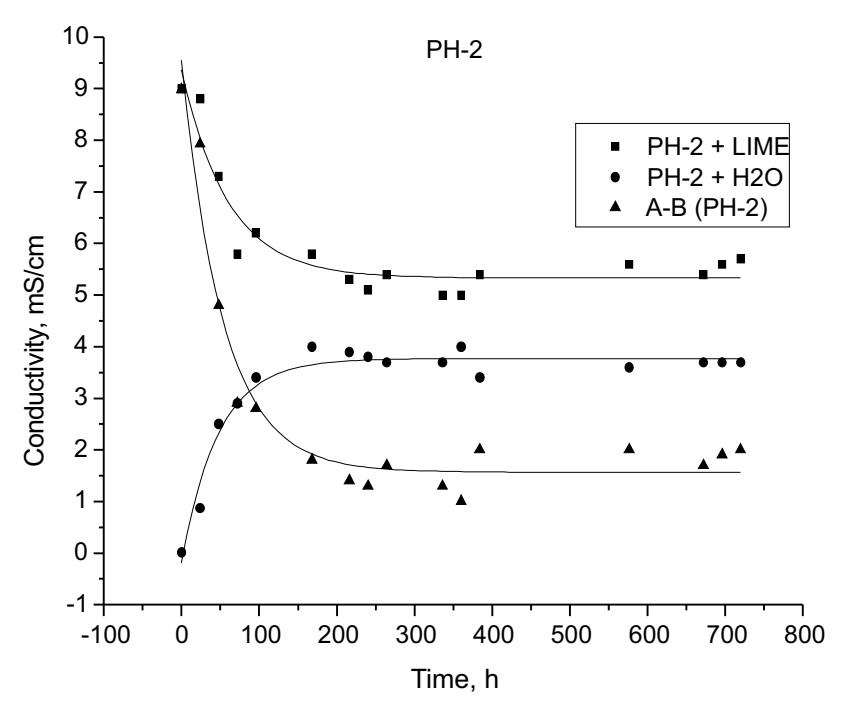

Figure 8 - Conductivity of ashes, graphics (A-B)

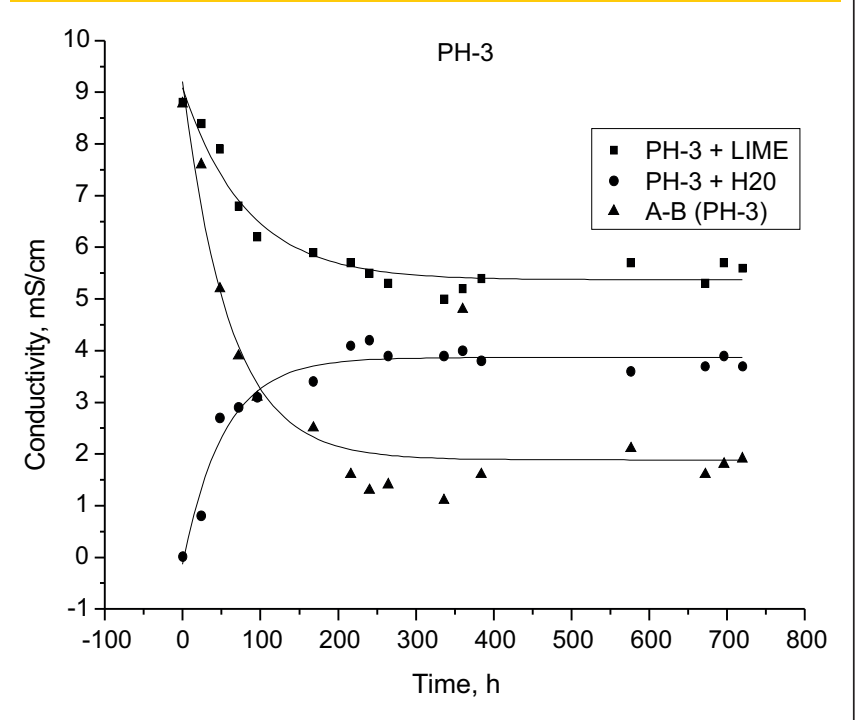

slightly minor than the others at shorter times, improving its behavior in longer periods, reaching a greater value than $\mathrm{M} 0$ at day 120 , Fig. [10]. The Fig. [11] shows the behavior of mortars and the compression strength limit established by IRAM 1654 norms, for mortars with addition of pozzolanic material. The norm establishes as an acceptable behavior a value of $75 \%$ strength respect to reference mortar M0. $\mathrm{MPH}-2$ and MPH-3 showed acceptable values, above $75 \%$ respect to M0 in all tests, with a behavior near to $85 \%$ at day 120 . Despite that $\mathrm{MPH}-1$ showed a value below $75 \%$ at day 7 , its behavior at older ages increased significantly, reaching a value higher than M0 at day 120 .

\section{Figure 9 - Conductivity of ashes, graphics (A-B)}

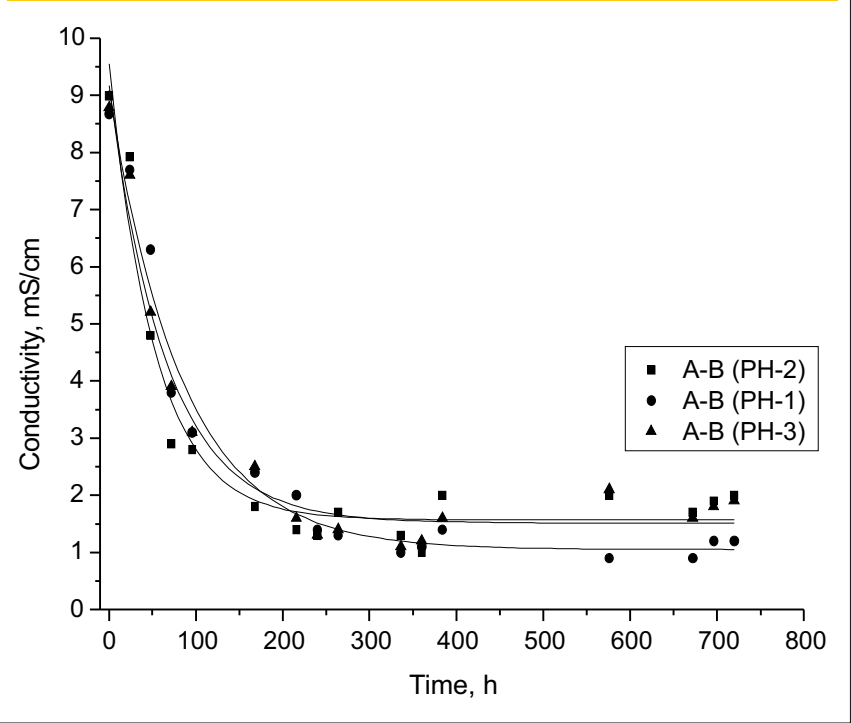


Table 2 - Compressive strength of probes at different ages

\begin{tabular}{|c|c|c|c|c|c|c|}
\hline & \multicolumn{6}{|c|}{ Compressive strength (Mpa) at different ages (days) } \\
\hline & 7 & 14 & 28 & 60 & 90 & 120 \\
\hline MO & 18.3 & 22.3 & 24.4 & 28.2 & 29.0 & 30.3 \\
\hline MPH-1 & 12.2 & 17.1 & 21.4 & 23.8 & 24.8 & 32.6 \\
\hline MPH-2 & 14.2 & 17.7 & 19.7 & 24.7 & 25.8 & 24.6 \\
\hline MPH-3 & 14.1 & 17.2 & 19.4 & 27.7 & 25.1 & 23.9 \\
\hline
\end{tabular}

\section{Conclusions}

The ashes of peanut husks might be used as supplementary material for cement, because they have a chemical composition according to pozzolans type $\mathrm{C}$, although the alkali content is a little high and could give unwanted reactions of the type alkali-aggregate in cement, therefore levels of addition should be low. The morphology of ashes depends on the burnt temperature of husks, therefore it is advisable to control this parameter to avoid the formation of crystalline phases in order to increase the reactivity of the ashes, being $500{ }^{\circ} \mathrm{C}$ a suitable temperature for the calcinations. The ashes can be added to cement up to $15 \%$ without altering the mechanical properties of compressive strength of mortars and keeping the values permitted by the norm for Argentina.

The addition of peanut husk ashes to local manufacture of cement is presented as a potential alternative to decrease the environmental pollution associated with the production process, also adding value to an abundant regional waste, providing important economic and environmental benefits.

\section{Figure 10 - Compression strength of cement mortars substituted with ashes}

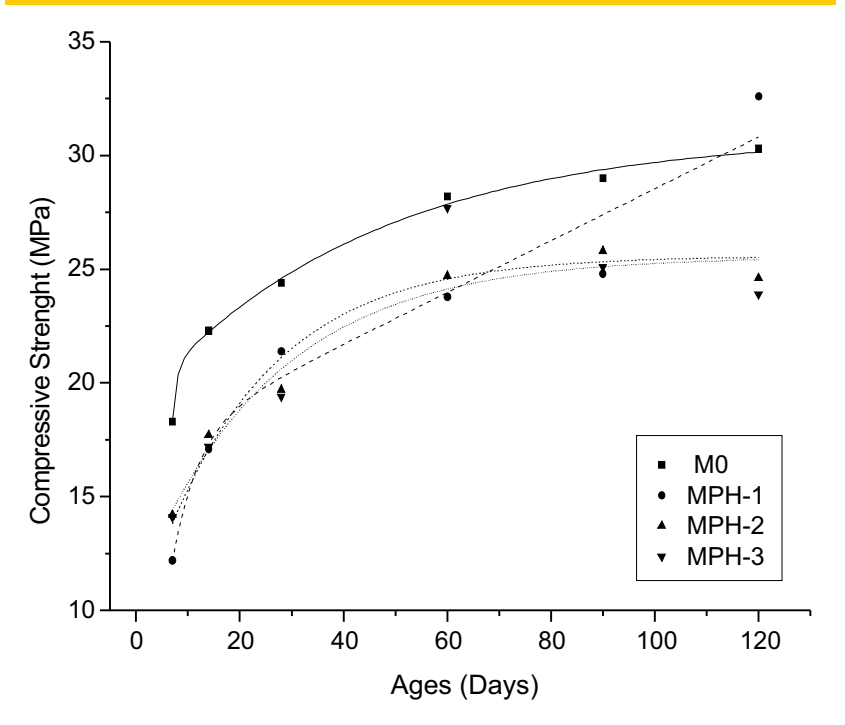

Additional studies on the mechanical and physical properties of mortars added with different dosages of peanut husk ashes are being carried out, and will be published in the future.

\section{Acknowledgements}

The authors wish to thank to the Experimental Center for Economical Housing (CEVE), the National Council of Scientific and Technological Research (CONICET), the Center for Research, Development and Transfer of Materials and Quality (CINTEMAC), and the Córdoba Regional Faculty of the National Technological University (UTN-FRC). The authors would like to thank to Diego Aguero from the CINTEMAC, to Ing. Liz Sablé from UTN-FRC, and to Arq. Eugenia Sipowicz from CEVE.

\section{References}

[01] Cámara Argentina del Maní. http://www.camaradelmani. com.ar/es/novedades. [accessed May. 21, 2012]

[02] Gatani M, Argüello R, Sesin S. Effect of chemical treatments

\section{Figure 11 - Behavior of cement mortars substituted with ashes respect to MO}

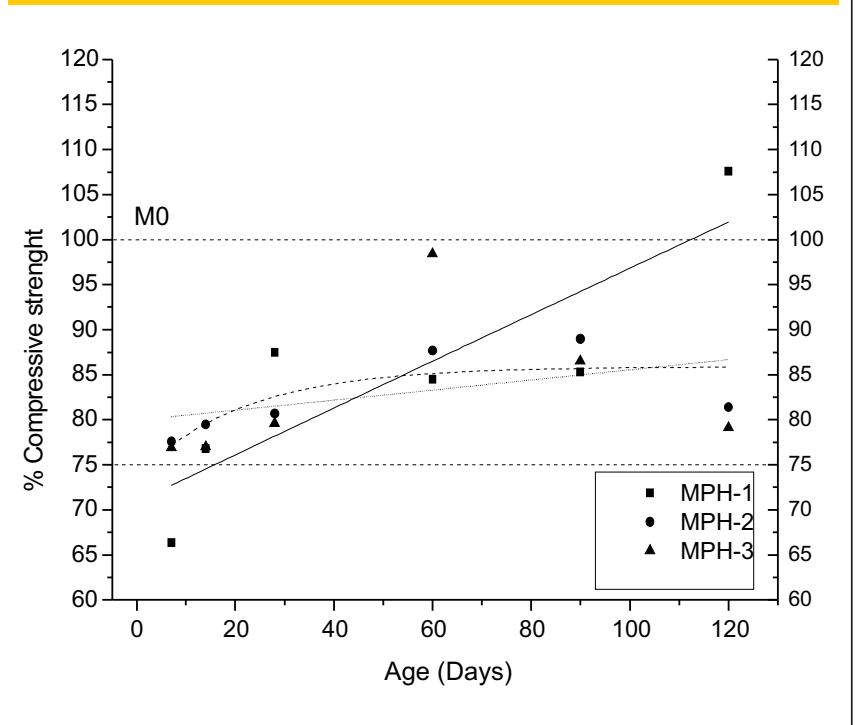


on the mechanical properties of peanut shell and cement blends. Materiales de Construcción, v. 60, n. 298, 2010; p. 137-47.

[03] Ravera MJA, Perez JD, Alonso R, Cotagro Coop. Agrop. Ltd. Procedimiento para obtener carbón activado y la instalación para llevarlo a cabo. AR Patent 45644A1, Novemeber 2005.

[04] Aceitera General Deheza. http://www.agd.com.ar/es/home. htm [accessed May. 21, 2011].

[05] Muller N, Harnish J. A blueprint for a climate friendly cement industry. Gland: WWF Lafarge Conservation Partnership 2008: 94p. http://assets.panda.org/downloads/english_report_Ir_pdf.pdf \{accessed Agost, 22, 2012).

[06] Hassan KE, Cabrera JG, Maliehe RS. The Effect of Mineral Admixtures on the Properties of High-Performance Concrete. Cement and Concrete Composites, v. 22, n.4, 2000; p. 267-271.

[07] Megat Johari MA, Brooks JJ, Kabir S, Rivard P. Influence of Supplementary Cementitious Materials on Engineering Properties of High Strength Concrete. Construction and Building Materials, v. 25, n. 5, 2011; p. 2639-2648.

[08] Shannag MJ. High Strength Concrete Containing Natural Pozzolan and Silica Fume. Cement and Concrete Composites, v. 22, n.6, 2000; p. 399-406.

[09] Lam L, Wong YL, Poon CS. Effect of Fly Ash and Silica Fume on Compressive and Fracture Behaviors of Concrete. Cement and Concrete Research, v. 28, n.2, 1998; p. 271-283.

[10] Papadakis VG, Antiohos S, Tsimas S. Supplementary Cementing Materials in Concrete: Part II: A Fundamental Estimation of the Efficiency Factor. Cement and Concrete Research, v. 32, n.10, 2002; p. 1533-1538.

[11] Papadakis VG, Tsimas S. Supplementary Cementing Materials in Concrete: Part I: Efficiency and Design. Cement and Concrete Research, v. 32, n.10, 2002; p. 1525-1532.

[12] Nair DG, Fraaij A, Klaassen AA, Kentgens APM. A Structural Investigation Relating to the Pozzolanic Activity of Rice Husk Ashes. Cement and Concrete Research, v. 38, n.6, 2008; p. 861-869.

[13] Cordeiro GC, Toledo Filho RD, Tavares LM, Fairbairn E, Hempel S. Influence of Particle Size and Specific Surface Area on the Pozzolanic Activity of Residual Rice Husk Ash. Cement and Concrete Composites, v. 33, n.5, 2011; p. $529-534$.

[14] Kartini K. Rice ash pozzolanic material for sustainability. International Journal of Applied Science \& Technology, v. 1, 2011; p. 169.

[15] Ganesan K, Rajagopal K, Thangavel K. Rice Husk Ash Blended Cement: Assessment of Optimal Level of Replacement for Strength and Permeability Properties of Concrete. Construction and Building Materials, v. 22, n.8, 2008; p. $1675-168$.

[16] Chatveera B, Lertwattanaruk P. Evaluation of Sulfate Resistance of Cement Mortars Containing Black Rice Husk Ash. Journal of Environmental Management, v. 90, n.3, 2009; p. 1435-1441.

[17] Biricik H, Akoz F, Berktay I, Tulgar A .Study of Pozzolanic Properties of Wheat Straw Ash. Cement and Concrete Research, v. 29, n.5, 1999; p. 637-643.

[18] Martirena Hernandez J. F, Middendorf B, Gehrke M,
Budelmann $\mathrm{H}$. Use of Wastes of the Sugar Industry As Pozzolana in Lime-Pozzolana Binders: Study of the Reaction. Cement and Concrete Research, v. 28, n.11, 1998; p. $1525-1536$

[19] Frias M, Villar E, Savastano H. Brazilian Sugar Cane Bagasse Ashes From the Cogeneration Industry As Active Pozzolans for Cement Manufacture. Cement and Concrete Composites, v. 33, n. 4, 2011; p. 490-496.

[20] Ganesan K, Rajagopal K, Thangavel K. Evaluation of Bagasse Ash As Supplementary Cementitious Material. Cement and Concrete Composites, v. 29, n.6, 2007; p. $515-524$.

[21] Foo KY, Hameed BH. Value-Added Utilization of Oil Palm Ash: A Superior Recycling of the Industrial Agricultural Waste. Journal of Hazardous Materials, v. 172, n. 2-3, 2009; p. 523-531.

[22] Cheah CB, Ramli M. The Implementation of Wood Waste Ash As a Partial Cement Replacement Material in the Production of Structural Grade Concrete and Mortar: An Overview. Resources, Conservation and Recycling, v. 55, n.7, 2011; p. 669-685.

[23] Martirena-Hernandez JF, Betancourt-Rodriguez S, Middendorf B, Rubio A, Martinez-Fernandez J, Machado Lopez J, Gonzales-Lopez R. Pozzolanic Properties of Residues of Sugar Industries. Materiales de Construcción, v. 50, n. 260, 2000; p. 71-78.

[24] Shih-Wei L, Chun-I L, LI-Hwa W. Kinetic study on lead (II) ion removal by adsorption onto peanut hull ash. Journal of the Taiwan Institute of chemical engineers, v. 42, n. 1, 2011; p. 166-72.

[25] Tse-Li L, Chun-I L. Performances of peanut hull ashes in bleacing water-degummed and alkali-refined soy oil. Journal of the Taiwan Institute of Chemical Engineers, v. 40, n.2, 2009; p. 168-73.

[26] Chaatveera B, Nimityongskul P. Use of coconut Husk Ash, Corn Ash and Peanut Shell Ash as Pozzolana. Journal of Science Technology, v. 16, n. 2, 1994; p. 1.

[27] Luxan MP, Madruga F, Saavedra J. Rapid Evaluation of Pozzolanic Activity of Natural Products by Conductivity Measurement. Cement and Concrete Research, v. 19, n. 1, 1989; p. 63-68.

[28] Paya J, Borrachero MV, Monzó J, Peris-Mora E, Amahjour F. Enhanced Conductivity Measurement Techniques for Evaluation of Fly Ash Pozzolanic Activity. Cement and Concrete Research, v. 31, n.1, 2001; p. 41-49.

[29] Gillot JE. Journal of Material in Civil Engineering, v. 4, 1995; p. 278.

[30] THAYLOR, H.F. Cement Chemistry. Ed. London Thomas Telford, 2 ed, 1997, 459p.

[31] Idorn GM. Expansive mechanisms in concrete. Cement and Concrete Research, v. 22, n. 6, 1992; p.1039-1046.

[32] Metha PK. Rice husk ash: a unique supplementary cementing material. Advances in Concrete Technology, v. 2, 1992; p. 407-431.

[33] Martirena-Hernandez JF, Betancourt-Rodriguez S, Middendorf B, Rubio A, Martinez-Fernandez J, Machado Lopez J, Gonzales-Lopez R. Pozzolanic Properties of Residues of Sugar Industries. Materiales de Construcción, v. 50, n. 260, 2000; p.71-78. 


\section{Norms}

ASTM-C618 12a. American Society for Testing and Materials Standard Specification for Coal Fly Ash and Raw or Calcined Natural Pozzolan for Use in Concrete. ASTM-C618 annu. Book ASTM Stand. 04.02 (1997) 294-296.

IRAM 1505:2005 Instituto Argentino de Normalización y Certificación. Agregados. Análisis granulométrico. 12 Pages.

IRAM 1520:2002 Instituto Argentino de Normalización y Certificación. Agregados finos. Métodos de laboratorio para la determinación de la densidad relativa real, de la densidad relativa aparente y de la absorción de agua. 14 Pages.

IRAM 1622:2006 Instituto Argentino de Normalización y Certificación. Cemento Portland Métodos de determinación de las resistencias a compresión y flexión. 25 Pages.

IRAM 1654:2068 Instituto Argentino de Normalización y Certificación. Puzolanas. Métodos de ensayos generales. 32 Pages.

IRAM 50000:2010 Instituto Argentino de Normalización y Certificación. Cemento. Cemento para uso general. Composición, características. Evaluación de la conformidad y condiciones de recepción. 42 Pages. 